
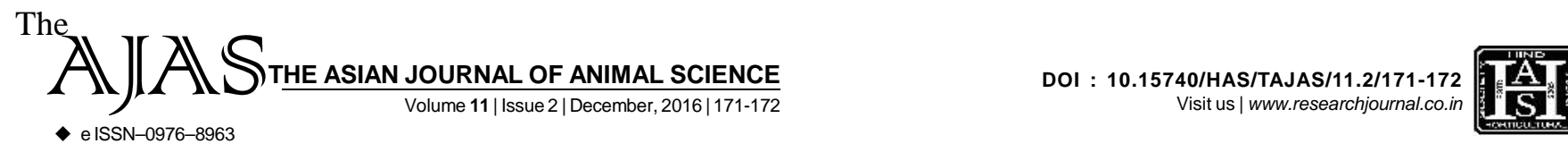

- e ISSN-0976-8963

Visit us | www.researchjournal.co.in $\mathrm{S}$

RESEARCH NOTE........

\title{
Influence of FecB gene on greasy fleecy yield in Malpura, Garole and their crossbreeds
}

KAVITA PATIL, B.R. ULMEK AND S.D. MANDAKMALE

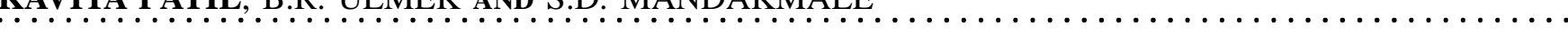

Author for Corresponding -

\section{KAVITA PATIL}

Krishi Vigyan Kendra (M.P.K.V.), Selsura, WARDHA (M.S.) INDIA

Email: kavita_patil26@rediffmail. com

See end of the article for Coopted authors'
ABSTRACT...... FecB gene played important role in GFY. However improvement in GM crosses with regards to growth traits was very slow as compared to the Malpura. Therefore back crossing of GM crosses with Malpura ram or ewe might be useful for improving production and reproduction traits.

KEY WORDS.......FecB, Garole, Malpura sheep, Wool yield

HOW TO CITE THIS ARTICLE - Patil, Kavita, Ulmek, B.R. and Mandakmale, S.D. (2016). Influence of FecB gene on greasy fleecy yield in Malpura, Garole and their crossbreeds. Asian J. Animal Sci., 11(2): 171-172. DOI : 10.15740/HAS/TAJAS/11.2/171-172.

ARTICLE CHRONICLE - Received : 08.11.2016; Accepted : 30.11.2016 